\title{
Estimating abundance and single-cell characteristics of respiring bacteria via the redox dye CTC
}

\author{
Barry F. Sherr ${ }^{1, *}$, Paul del Giorgio ${ }^{2}$, Evelyn B. Sherr ${ }^{1}$ \\ ${ }^{1}$ College of Oceanic and Atmospheric Sciences, Oregon State University, 104 Ocean Admin, Corvallis, Oregon 97331-5503, USA \\ ${ }^{2}$ Horn Point Laboratory, University of Maryland Center for Environmental Science, PO Box 775, Cambridge, \\ Maryland 21613, USA
}

\begin{abstract}
The redox dye 5-cyano-2,3-ditolyl tetrazolium chloride (CTC) is used in aquatic sciences as a vital stain for enumeration of respiring bacteria in situ. Questions concerning its efficacy have been raised. We propose that the abundance of CTC-positive (CTC+) bacteria is a useful parameter in microbial ecology based on the following information: (1) Taxonomically diverse strains of aerobic, heterotrophic marine bacteria reduce CTC to its fluorescent product. (2) The proportion of CTC+ cells in laboratory cultures and in bacterioplankton assemblages varies in meaningful ways: the proportion of CTC+ cells is greatest for bacteria in log-phase growth, and lowest for bacteria in late stationary phase; particle-associated bacteria in various marine environments exhibit a higher percentage of CTC+cells compared to bacteria freely suspended in the water column; the proportion of CTC+ cells in a bacterioplankton assemblage can be increased by an order of magnitude or more by addition of substrate, in the absence of net change in bacterial numbers. (3) Flow cytometric analysis shows a strong relationship between characteristics of CTC+ cells (abundance, size, red fluorescence) and rates of leucine incorporation by bacterial assemblages. We suggest that CTC+ cells represent those bacteria characterized by a high level of metabolic activity, and that cells which show no apparent reduction of CTC have either low or no metabolic activity. Some portion of CTC-negative (CTC-) cells may have sufficient RNA content, and/or ability to assimilate labile substrates at dilute concentrations, to be identifiable as 'active' via indices of cell-specific rRNA content or of microautoradiography. Quantitative differences in metabolism between 'highly active' CTC+ cells, and 'less active' CTC-cells have yet to be determined
\end{abstract}

KEY WORDS: Bacteria $\cdot$ CTC $\cdot$ Metabolic activity $\cdot$ Respiration

\section{INTRODUCTION}

Identifying the proportion of bacterioplankton which is metabolically active, in contrast to the proportion which is dormant or dead, has long been a goal in aquatic microbial ecology. Stevenson (1978) proposed that most bacterial cells present in aquatic systems were inactive, i.e. either dormant or dead. Subsequent research has demonstrated that under conditions of low organic substrate supply, heterotrophic marine bacteria can enter a phase of long-term survival in

•E-mail: sherrb@oce.orst.edu which the rate of endogenous metabolism is low (reviewed in Morita 1997). Bacteria deprived of nutrients form ultramicrocells similar in size to that of in situ bacteria (Moyer \& Morita 1989, Nystrom et al. 1990). In laboratory culture, starved marine Vibrio sp. exhibit reduced DNA and RNA content per cell, as well as reduced rates of protein synthesis (Moyer \& Morita 1989, Nystrom et al. 1990). Starved bacteria have also been shown to synthesize starvation-specific proteins, which may aid the survival of cells in low-nutrient environments (Kjelleberg et al. 1993).

Non-growing bacteria in a natural assemblage may thus be in a different metabolic state, referred to as a state of starvation-survival (Morita 1982, 1997), com- 
pared to actively growing cells in the same assemblage. Another designation used to compare active and inactive bacterial cells has been 'culturable' cells that can be grown on nutrient agar, versus 'viable but nonculturable' cells that are alive, and have some level of metabolic activity, but cannot be grown on agar (Roszak \& Colwell 1987). A recent study of the viability of Escherichia coli and Salmonella typhimurium in seawater indicated that single strains of bacteria can exhibit a variety of metabolic states in the natural environment (Lopez-Amoros et al. 1995). It is also presumed that some fraction of cells in a bacterioplankton assemblage may be non-viable, or dead (Jepras et al. 1995, Mason et al. 1995, Zweifel \& Hagström 1995, Heissenberger et al. 1996).

Determination of viability by ability of single cells to form bacterial colonies on agar plates (number of colony forming units, or CFU) was an early method that is now recognized as yielding substantial underestimates of the number of viable cells because apparently not all marine bacteria can be grown on agar (Roszak \& Colwell 1987, Lee \& Fuhrman 1991, Suzuki et al. 1997). Button et al. (1993) developed an alternate, more sensitive approach for determining the proportion of viable cells among seawater bacteria based on growth of single cells in dilution culture. In contrast to culture methods, cell-specific assays to detect activity/viability in bacteria are attractive in that data can be obtained using short-term incubations, and the entire bacterial assemblage can be inspected for activity. In microautoradiography, for example, the proportion of bacteria that has assimilated radiolabeled organic substrates added at nanomolar concentrations is determined (e.g. Meyer-Reil 1978, Tabor \& Neihof 1982, Douglas et al. 1987, Pedrós-Alió \& Newell 1989, Grossman 1994)

Another approach used to distinguish 'active' from 'inactive' cells is identification of cells with an active electron transport system (ETS). The first compound used for this purpose was the tetrazolium dye INT (2(4-iodophenyl)-3-(4-nitrophenyl)-5-phenyl tetrazolium chloride), which is reduced by the bacterial ETS to water-insoluble formazan crystals. Bacteria that have reduced INT, and thus have an active ETS, are identified via light microscopy by the presence of opaque formazan crystals accumulated in and around the cell (Zimmerman et al. 1978, Tabor \& Neihof 1982, Newell et al. 1986, Dufour \& Colon 1992, Posch et al. 1997). A variant of the INT approach is the use of the fluorogenic tetrazolium dye CTC (5-cyano-2,3-ditolyl tetrazolium chloride). CTC is water soluble and nonfluorescent in its oxidized state, but becomes highly fluorescent and insoluble when reduced (Stellmach 1984, Rodriguez et al. 1992). Bacteria with an active ETS thus accumulate the reduced red-fluorescing for- mazan compound in and around the cell, which can be easily visualized via epifluorescence microscopy using green or blue light excitation. By counter-staining with the blue-fluorescing fluorochrome DAPI, each bacterial particle can be inspected for presence of reduced CTC (del Giorgio \& Scarborough 1995, Gasol et al. 1995, Choi et al. 1996). In a study with Escherichia coli, Smith \& McFeters (1996) reported that the amount of formazan produced via reduction of CTC was 30 - to 150 -fold greater than the amount of formazan produced from INT. Based on these and subsequent results (Smith \& McFeters 1997), it appears that the reduction of INT to formazan is less tightly coupled to respiratory activity compared to reduction of CTC in whole E. coli cells

More recently, other cell-specific methods have been proposed to distinguish live, or viable, bacteria from dead, or non-viable, bacteria. Certain fluorogenic compounds can diffuse through bacterial cell walls and membranes only when the integrity of the membrane and cell wall has been compromised. Such compounds include propidium iodide, ethidium bromide, oxonol, and the Molecular Probes dye TOPRO-1 (Jepras et al. 1995, Lopez-Amoros et al. 1995, McFeters et al. 1995, Williams et al. 1998). In theory, if a bacterial cell is stained with one of these compounds, it is non-viable. Universal 16S rRNA-targeted oligonucleotide probes have been used to identify bacterial cells which contain sufficient ribosomal-RNA to be potentially metabolically active (Kemp et al. 1993, Kramer \& Singleton 1993, Karner \& Fuhrman 1997). Zweifel \& Hagström (1995) developed a method for specifically DAPI staining only the nucleoid region of in situ bacterial cells, i.e. eliminating non-specific DAPI staining of other cellular components, and suggested that only those cells with identifiable stained nucleoid regions should be considered to be alive. In addition, using transmission electron microscopy, Heissenberger et al. (1996) found that for freely suspended bacterial cells in seawater samples, $34 \%$ of cells appeared intact, $42 \%$ of cells exhibited damaged cell walls and membranes, and $24 \%$ of cells appeared to lack any internai structure.

As these methods are used and compared in various systems, it has become apparent that different approaches yield different estimates of the proportion of bacterial cells that are alive, viable, and metabolically active. In particular, the CTC method, which identifies bacteria with active ETSs, generally results in estimates of active cells in the range of 1 to $10 \%$ of the bacterioplankton assemblage. Other methods yield much higher estimates ( 30 to $60 \%$ ) of live and metabolically active cells. Karner \& Fuhrman (1997) reported that in bacterial assemblages in coastal seawater, an average of $29 \%$ of cells had visible nucleoids, $49 \%$ took up added radiolabeled compounds in 
autoradiographic assays, and 56\% had detectable amounts of rRNA via universal probe binding. In contrast, in their study, on average only $0.7 \%$ of cells were estimated to have active ETSs using a CTC assay. Ullrich et al. (1996) proposed that the CTC approach yields underestimates of active bacterial cells because the redox compound is toxic to bacteria. Others have suggested that not all bacteria can effectively reduce CTC (Thom et al. 1993, Srnith \& McFeters 1997).

Here, we address criticisms of use of the CTC assay to detect ETS-active bacteria, and consider how the results of the CTC assay should be interpreted. We argue, based on both past work and on recent results in our laboratories, that the CTC assay is in fact a useful tool in microbial ecology, and suggest that the results of this method provide fundamentally different information compared to other cell-specific methods that test for cell viability. The new results reported here include a survey of the ability of taxonomically diverse marine bacterial isolates to reduce CTC to its fluorescent product, a comparison of the percentage of CTC-positive (CTC+) cells among freely suspended bacteria and among particle-associated bacteria in 3 regions of the sea, and a comparison of the percentage of CTC+ cells with other indices of bacterial activity and cell-specific characteristics in grazer manipulation experiments with lake bacteria.

\section{MATERIAL AND METHODS}

Test of strain-specific ability to reduce CTC with laboratory cultures of marine bacteria. We were able to test 27 bacterial cellular clones isolated from Oregon coastal waters. Out of 27 clones, 26 were isolated from offshore surface water samples on marine R2A agar plates in the laboratory of S. Giovannoni (Suzuki et al. 1997). Each of these cellular clones was phylogenetically identified by rRNA gene sequencing (Suzuki et al. 1997). The other strain, Pseudomonas putida, was isolated by Choi et al. (1996). Prior to testing for reactivity to CTC, the individual strains of bacteria were freshly inoculated, and colonies were grown up for 1 wk on marine R2A agar plates. For each bacterial colony, a flame-sterilized wire loop was used to collect a portion of the colony, which was then stirred into $1 \mathrm{ml}$ of $0.2 \mu \mathrm{m}$ filtered and autoclaved seawater in a $2 \mathrm{ml}$ plastic cryovial. Sterile technique was carefully maintained to preclude cross-contamination between separate bacterial strains. Filter-sterilized CTC was added to the samples to yield a final concentration of $5 \mathrm{mM}$, and the vials were incubated in the dark at $20^{\circ} \mathrm{C}$ for $2 \mathrm{~h}$. At the end of that time, a subsample from each vial was counterstained with DAPI and filtered onto a $0.2 \mu \mathrm{m}$ black-stained membrane filter, which was mounted onto a slide and inspected at $1000 \times$ via epifluorescence microscopy to detect CTC fluorescence associated with bacterial cells (Choi et al. 1996)

Proportion of CTC+ cells among freely suspended versus particle-associated bacteria in marine systems. Seawater samples were collected in the upper water column in 3 regions of the ocean: (1) the mid-Atlantic continental shelf off Cape Hatteras, from nearshore to the shelf slope, $74.6^{\circ}$ to $75.9^{\circ} \mathrm{W}$ and $35.5^{\circ}$ to $36.6^{\circ} \mathrm{N}$; (2) the Chukchi Sea off Alaska, $157^{\circ}$ to $168^{\circ} \mathrm{W}$ and $66^{\circ}$ to $76^{\circ} \mathrm{N}$; and (3) the northwestern Mediterranean Sea off Villefranche-sur-Mer, $43^{\circ} 41^{\prime} \mathrm{N}, 7^{\circ} 19^{\prime} \mathrm{E}$. For the Atlantic continental shelf region, the same stations were occupied during 2 seasons; in March 1996 when water temperatures over the shelf were cool, 4 to $11^{\circ} \mathrm{C}$, and in July 1996, when surface water temperatures were warmer, 20 to $26^{\circ} \mathrm{C}$. Water temperatures were cold in the Chukchi Sea, -1.8 to $0.8^{\circ} \mathrm{C}$, and temperate in the Mediterranean, 18 to $22^{\circ} \mathrm{C}$.

Percent active bacteria was determined for seawater samples as described in Choi et al. (1996). Briefly, CTC was added to $0.9 \mathrm{ml}$ subsamples of unfiltered seawater to yield a final concentration of $5 \mathrm{mM} \mathrm{CTC}$, and the samples were incubated in the dark at room temperature for periods of 2 to $3 \mathrm{~h}$. At the end of the incubation, samples were preserved with $5 \%$ final concentration of formalin and frozen. Upon return to the laboratory, the samples were thawed, counterstained with DAPI, filtered onto $0.2 \mu \mathrm{m}$ black-stained membrane filters, and mounted onto slides. The filters were inspected immediately via epifluorescence microscopy as described in Choi et al. (1996). All samples were inspected for the proportion of visibly ETS-active (CTC+) cells among bacterial cells randomly dispersed on the filters (freely suspended cells). In a subset of samples in which the abundance of amorphous organic particles was high, we also enumerated the number of bacteria on individual particles, and the number of those bacteria that had red fluorescence. For each such slide examined, from 15 to 30 particles were inspected. The total number of slides inspected for suspended bacteria (number of slides inspected for particle-associated bacteria) was 110 (27) and 89 (51) for Atlantic Shelf samples in March and July; 11 (11) for Mediterranean samples, and 32 (15) for Arctic Ocean samples. The mean value \pm 1 standard deviation for bacterial abundance, for \% CTC+ cells among freely suspended bacteria, and for \% CTC+ cells for particle-associated bacteria was calculated for each sample set.

We also carried out a test to compare our CTC assay protocol with that used by Karner \& Fuhrman (1997), in which $30 \mathrm{ml}$ seawater samples were filtered onto membrane filters, the filter surface was flooded with a $4 \mathrm{mM}$ CTC solution, and the filters were incubated for periods of time. We incubated triplicate seawater samples 
with $5 \mathrm{mM} \mathrm{CTC}$ that were: $1 \mathrm{ml}$ liquid samples in plastic cryovials, $3 \mathrm{ml}$ samples settled onto $0.2 \mu \mathrm{m}$ membrane filters, and $30 \mathrm{ml}$ samples settled onto $0.2 \mu \mathrm{m}$ membrane filters.

Comparison of CTC-reduction and other indices of cell activity in a grazer manipulation experiment with freshwater bacteria. A manipulation experiment was carried out to assess the effect of grazing by protozoans and Daphnia on the structure of bacterioplankton assemblages. Ten liters of water from oligotrophic Lac Croche (Quebec, Canada) were prefiltered through GF/C glass fiber filters and Nuclepore $0.8 \mu \mathrm{m}$ membranes, to eliminate protists and most phytoplankton. The filtered water was amended with a $40 \mathrm{nM}$ concentration of an amino acid mixture (Sigma Scientific) to stimulate bacterial growth, and stored in the dark at $20^{\circ} \mathrm{C}$ for $24 \mathrm{~h}$ before the experiments. $250 \mathrm{ml}$ aliquots of this water were then poured into 12 acid-washed, $300 \mathrm{ml}$ plastic jars. Four jars were used as controls. Another 4 jars were amended with $D$. galeata at a density of 50 ind. $\mathrm{l}^{-1}$. The $D$. galeata had been reared in an aquarium and fed Scenedesmus sp. Twenty-four hours before the experiment, the $D$. galeata were gently collected on a nylon screen, and then placed in vials with the filtered water from Lac Croche. The water was changed 3 times during the preincubation period so that the $D$. galeata could clear their gut contents. The Daphnia were then pipetted individually into the experimental vials. The last 4 vials were amended with a culture of heterotrophic flagellates, which were isolated from lake water and cultured in rice media. Ten $\mathrm{ml}$ of flagellate suspension was added to each vial, resulting in a final flagellate density of approximately 3000 organisms $\mathrm{ml}^{-1}$. The vials were placed in the dark at $20^{\circ} \mathrm{C}$, and samples were taken at the beginning of the experiment $\left(t_{0}\right)$ and at $6,12,24,36$ and $48 \mathrm{~h}$. The samples were processed immediately as described below.

Total bacterial abundance and the number of active bacteria were determined using flow cytometry. A FACScan (Becton Dickinson, Mountain View, CA) flow cytometer was used for all cell counts. This standard instrument was equipped with a $15 \mathrm{~mW}, 488 \mathrm{~nm}$, aircooled argon-ion laser, and a $70 \mu \mathrm{m}$ nozzle. The instrument has fixed alignment of laser and optics components. Sheath fluid was a particle-free solution (Hematall, Fisher Scientific). The instrument was interfaced with a HP 9000 Series, Model 310 computer and was controlled using the LYSIS II software (Becton Dickinson), which was also used to analyze the acquired data. The low sample flow rate $\left(12 \mu \mathrm{min}^{-1}\right)$ was always used for bacterial enumeration. The cytometric enumeration of bacteria was based on the determination of the ratio of stained cells to an internal bead standard added to the sample. Green fluorescing microbeads (Fluoresbrite Microspheres, Polysciences,
Warrington, PA) of $0.92 \mu \mathrm{m}$ diameter were used as internal standard for all cell counts. For total cell counts, bacteria were stained with the green nucleic acid stain SYTO 13 and enumerated following del Giorgio et al. (1996). For the number of active cells, samples were incubated in $5 \mathrm{mM}$ of CTC for $2 \mathrm{~h}$, and then enumerated following del Giorgio et al. (1997). Bacterial activity was independently quantified as rates of leucine incorporation, a proxy for bacterial production, following Smith \& Azam (1992).

\section{RESULTS}

\section{Ability to reduce CTC among marine bacterial isolates}

All of the 27 bacterial strains tested showed an equally good capacity to reduce CTC to the fluorescent

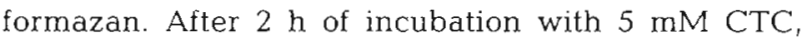
nearly $100 \%$ of cells of each strain tested was full of red-fluorescing precipitant. The isolated bacterial strains included representatives of the most abundant groups of marine bacteria: 9 strains of alpha proteobacteria; 9 strains of gamma proteobacteria; 6 Grampositive bacterial strains; and 2 strains in the flexibacteria group. Strains in the genera Bacillus, Micrococcus, Vibrio, Aeromonas, Azospirillum, Oceanospirillum, Alterimonas, Pseudomonas, Blastobacter, Sphingomonas, and Flavobacterium were among those tested (Suzuki et al. 1997).

\section{Comparison of percentage of CTC+ cells among freely suspended bacteria and among particle- attached bacteria in marine systems}

The mean number of bacteria for the 4 sites was 0.88 $\times 10^{-6}$ cells ml- ${ }^{-1}$ for the Atlantic shelf in March, $0.37 \times$ $10^{-6}$ cells $\mathrm{ml}^{-1}$ for the Atlantic shelf in July, $0.39 \times 10^{-6}$ cells $\mathrm{ml}^{-1}$ for the Mediterranean, and $0.21 \times 10^{-6}$ cells $\mathrm{ml}^{-1}$ for the Arctic Ocean. In each of these regions, we found that particle-associated bacteria were proportionally more active $(19.1 \pm 12.4$ to $35.2 \pm 7.8 \% \mathrm{CTC}+)$ compared to freely suspended bacteria $(1.2 \pm 1.7$ to 6.5 $\pm 1.9 \% \mathrm{CTC}+$ ) (Fig. 1 ). The mean percentage of CTC+ cells for particle-associated compared to freely suspended bacteria ranged from 3.7 -fold greater in the Mediterranean sample set to 23.5 -fold greater in the July Atlantic shelf sample set. In the 2 sample sets characterized by colder water, the March Atlantic shelf and the Arctic Ocean data, particle-associated bacteria were on average 6 -fold more active compared to freely suspended bacteria, based on percentage of CTC+ cells. 


\section{Relation of CTC reduction to other parameters of bacterial activity and to cell characteristics in the grazer manipulation experiment}

The manipulation of the grazer community had profound effects on the structure and function of the natural freshwater bacterioplankton assemblage, in terms of bacterial production, mean cell size, the number and proportion of active $(\mathrm{CTC}+)$ cells, and the characteris tics of these active cells, as determined using flow cytometry. The initial bacterial abundance in the controls averaged $5.5 \times 10^{6}$ cells $\mathrm{ml}^{-1}$, with $15 \%$ of active $(\mathrm{CTC}+)$ cells; rates of leucine uptake averaged $135 \mathrm{pmol} \mathrm{l}^{-1} \mathrm{~h}^{-1}$. After $36 \mathrm{~h}$ of incubation in the absence of grazers, total abundance in the controls reached 15 $\times 10^{6}$ cells $\mathrm{ml}^{-1}$ (Fig. 2A). Total abundance decreased in both the flagellate and Daphnia treatments after $36 \mathrm{~h}$ although the number of CTC + bacteria increased and remained constant, respectively (Fig. 2A). Microscopic examination revealed the development of abundant filamentous bacteria that were resistant to grazing in the flagellate treatment. As a result, the proportion of active cells was highest in the flagellate treatment, followed by the Daphnia treatment and the controls (Fig. 2B). In spite of large increases in bacterial abundance, rates of leucine incorporation remained low in the controls throughout the experiment, relative to the rates measured in the 2 grazing treatments, particularly in the containers with flagellates (Fig. 2C).

Individual characteristics of the bacterial cells can be derived from cytometric data. The intensity of green fluorescence from SYTO 13 is related to the nucleic acid content of the cells, which is roughly proportional to cell volume (Gasol \& del Giorgio in press). The scatter of light at right angles, side light scatter, is also roughly proportional to cell volume, at least in the

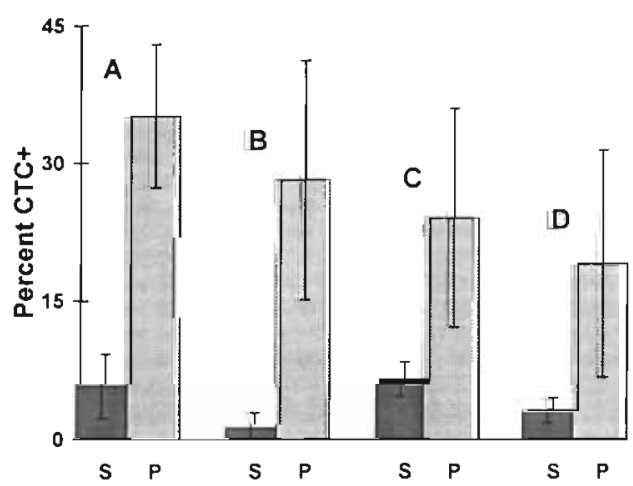

Fig. 1. Comparison of mean values \pm 1 standard deviation of the percentage of CTC+ cells for freely suspended bacteria (S) and for particle-associated bacteria (P) at 4 sites. (A) Atlantic shelf, March 1996; (B) Atlantic shelf, June 1996; (C) Mediterranean Sea, June 1996; (D) Chukchi Sea, Arctic Ocean, June 1996 range of bacterioplankton cell sizes. Mean cell size of the entire assemblage, as evidenced both by mean green fluorescence (Fig. 2D), and also by mean side light scatter (data not shown), was highest in the flagellate treatment, followed by the Daphnia treatment and remained low in the controls, after $36 \mathrm{~h}$. Individual characteristics of CTC+ cells can also be derived from cytometric parameters. Again, side light scatter is a relative index of cell size of the CTC+ cells, whereas the mean red fluorescence (FL3) emission per cell is related to the amount of formazan produced by each cell, which is in turn an index of respiratory rate in individual cells (Smith \& McFeters 1997). There were significant differences in both parameters among treatments after $36 \mathrm{~h}$. Active cells were on average larger (Fig. 2E), and the mean red fluorescence per cell greater (Fig. 2F), in the treatments with grazing than in the controls. These results suggest that the presence of grazers had a large impact on the structure of this bacterioplankton assemblage, but the effects of grazing were not evident when only the total bacterial abundance and mean cell size were considered. The most profound changes were evidenced as large shifts in the rates of leucine incorporation, which were the result of changes in the number, proportion, and characteristics of highly active cells, as measured by CTC and flow cytometry (Fig. 3). We discuss the implications of these changes below

\section{DISCUSSION}

\section{Previous uses of CTC}

There is a long history of use of tetrazolium salts as markers of dehydrogenase activity and cell metabolism in cell biology (Nybroe 1995). The use of tetrazolium salts to detect respiring bacteria is more recent, however. Zimmerman et al. (1978) proposed the use of INT to enumerate respiring planktonic bacteria, and others later used and perfected the method (Baker \& Mills 1982, Newell 1984, Dufour \& Colon 1992, Posch et al. 1997). INT is reduced to a colored but non-fluorescent formazan compound, so detection of intracellular deposits of formazan in planktonic bacteria with light microscopy posed some difficulties and enumeration was imprecise. The first published report of the use of CTC was by Stellmach (1984), who early on recognized the advantages of working with a fluorescent formazan. Initial applications of CTC were on Ehrlich ascites tumor cells and other mammalian cells (Stellmach 1984, Langer 1985, Severin \& Seidler 1992 Nybroe 1995)

Rodriguez et al. (1992) were the first to show that CTC could be used to detect respiring bacteria, both in 
culture and from natural water samples. Researchers studying physiological responses of bacteria to environmental conditions began to use the CTC method on a variety of cultured bacterial species: Kaprelyants \& Kell $(1993 a, b)$ studied starvation responses in Micrococcus luteus; Lopez-Amoros et al. (1995) studied Escherichia coli survival in seawater; Bovill et al. (1994) assessed the physiological condition in Listeria; and Pyle et al. (1995) combined CTC with antibodies to detect active cells of $E$. coli, Salmonella typhimurium and Klebsiella pneumoniae in natural waters.

There has also been increasing interest in the application of CTC to detect respiring cells in natural bacte-
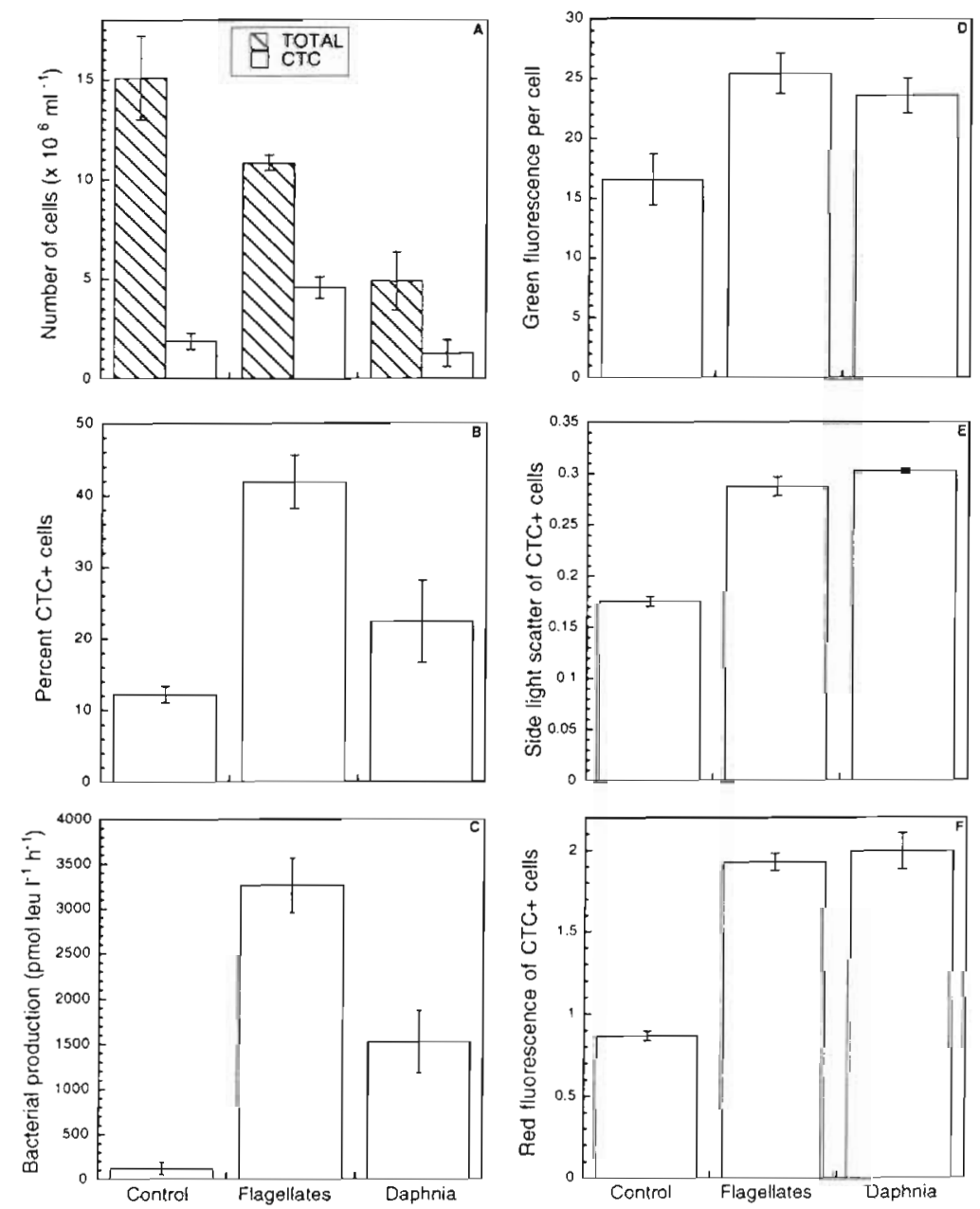

Fig. 2. Summary results of a grazer manipulation experiment, where lake bacterioplankton were exposed to different types of grazing. Bars are the average of 3 replicates for each treatment (control, +flagellates and +Daphnia galeata) taken $36 \mathrm{~h}$ after the start of the experiment. Error bars are the standard error. (A) Total bacterial abundance and abundance of CTC+ cells. (B) Proportion of CTC+ cells. (C) Rates of leucine incorporation. (D) Mean green fluorescence per cell, measured in the flow cytometer after the cells were stained with the green nucleic acid stain SYTO 13. (E) Mean side light scatter of CTC+ cells, measured in the flow cytometer. (F) Mean red fluorescence emission per CTC+cell, measured in the flow cytometer rioplankton assemblages, beginning with the work of Rodriguez et al. (1992). Schaule et al. (1993) and Coallier et al. (1994) assessed the number of respiring cells in drinking water; del Giorgio \& Scarborough (1995) and del Giorgio et al. (1997) measured the number of active cells in different types of lakes. Lovejoy (1996) CTC method has also been used to assess the physio logical condition of bacteria in biofilms ( $\mathrm{Yu} \& \mathrm{McF}$ eters 1994a,b, Kalmbach et al. 1997) and in soils (Winding et al. 1994, Heijnen et al. 1995). Epstein \& Rossel (1995) and Epstein (1997) used CTC-labeled bacteria to measure flagellate grazing rates.

\section{Methodological aspects of the CTC technique}

The use of CTC as a marker of metabolic activity in individual bacterial cells is subject to the same type of limitations described for tetrazolium salts in general (Burton \& Lanza 1986, Thom et al. 1993). One of the main concerns is the permeability of CTC to different types of bacterial cells, but our own culture work suggests that a wide variety of bacterial strains isolated from seawater are able to take up and reduce CTC to its fluorescent formazan. Our results are supported by other laboratory studies, in which all bacterial strains tested to date have shown positive results with CTC (Kaprelyants \& Kell 1993a,b, Bovill et al. 1994, LopezAmoros et al. 1995, Nybroe 1995, Pyle et al. 1995, Choi et al, 1996, Smith \& MCFeters 1997). Thus, potential variability among individual bacterial strains in natural systems with respect to ability to reduce CTC does not appear to be a major limitation of the technique.

Two other issues are of importance for results obtained with CTC: the concentration of CTC used and the incubation time of cells with CTC. The intracellular reduction of CTC appears to be concentration-dependent (Rodriguez et al. 1992), and several authors have shown that the highest and most consistent number of stained cells is obtained with CTC concentrations ranging from 2.5 to $5 \mathrm{mM}$ (Rodriguez et al. 1992, del Giorgio \& 

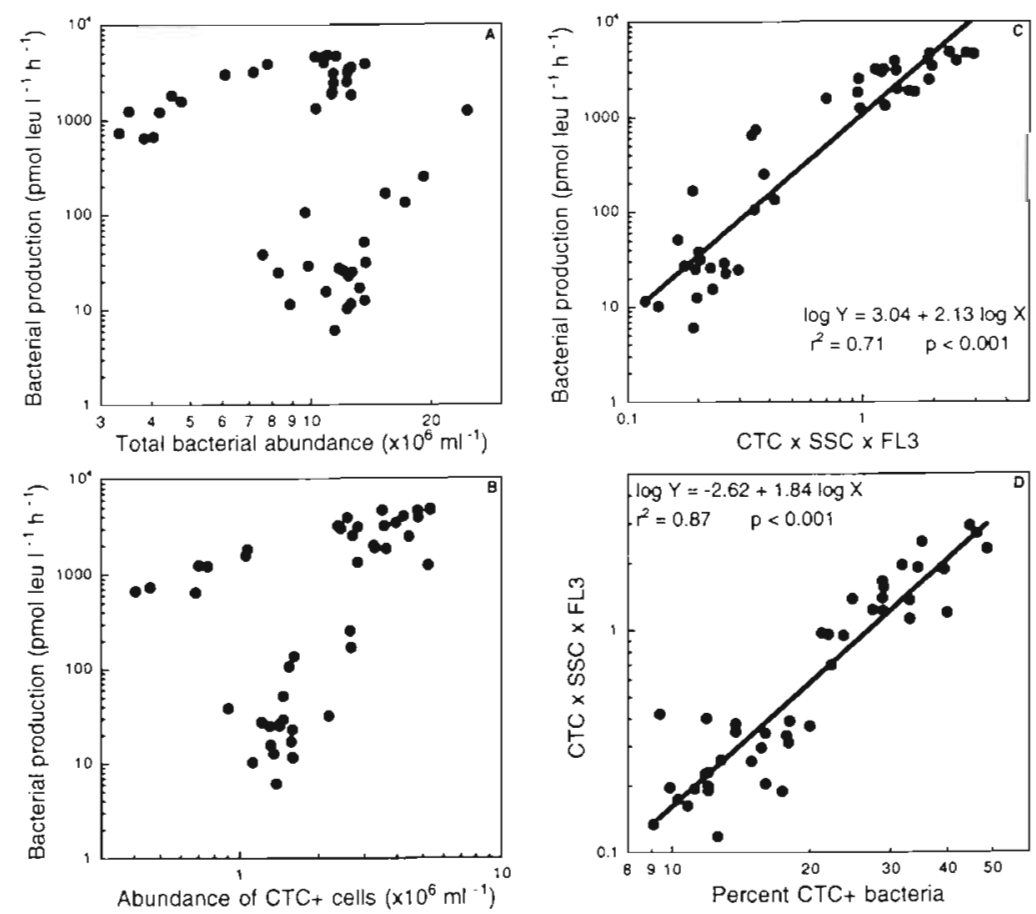

Fig. 3. Results of grazer manipulation experiment, where each point is now the individual sample taken from each of the 3 treatments (control, +flagellates, +Daphnia galeata) at different times during the incubation (0 to $36 \mathrm{~h}$ ). (A) Relationship between rates of leucine incorporation and the total abundance of bacteria. (B) Relationship between rates of leucine incorporation and the abundance of CTC+ cells. (C) Relationship between rates of leucine incorporation and product of CTC+ abundance (CTC), relative size of CTC+ cells, as measured with side light scatter (SSC) in the flow cytometer, and average red fluorescence emission of CTC+ cells (FL3), measured with the flow cytometer

Scarborough 1995, Choi et al. 1999, in this issue). Below this range, the number of stained cells is usually lower, and above about $10 \mathrm{mM}$, the number of stained cells also tends to decline, presumably due to toxicity of CTC or of its formazan product (Choi et al. 1999). In studies in which CTC concentrations lower than 2.5 to $5 \mathrm{mM}$ were used, e.g. that of Lovejoy et al. (1996), the reported abundances of CTC+ bacterial cells may be artefactually low.

Incubation times used by different authors vary greatly, too. Del Giorgio \& Scarborough (1995) used $8 \mathrm{~h}$

Table 1. Estimates of abundance of CTC+ bacteria in seawater: comparison of incubation of liquid samples versus incubation of samples on filters. Mean of triplicate samples \pm 1 standard deviation

\begin{tabular}{|lc|}
\hline Treatment & $\begin{array}{c}\text { Abundance of CTC+ bacteria } \\
\left(10^{-4} \mathrm{cells} \mathrm{m}^{-1}\right)\end{array}$ \\
\hline Liquid samples & $3.60 \pm 0.58$ \\
Filtered samples $(3 \mathrm{ml})$ & $3.72 \pm 0.56$ \\
Filtered samples $(30 \mathrm{ml})$ & $1.20 \pm 0.54$ \\
\hline
\end{tabular}

incubations for lake samples, whereas del Giorgio et al. (1996) found that somewhat longer incubations were needed to attain maximum number of CTC+ cells in oligotrophic Mediterranean samples. Other authors have used shorter incubation times (Rodriguez et al. 1992, Schaule et al. 1993, Choi et al. 1996, Lovejoy et al. 1996). Del Giorgio et al. (1996) found that incubation times could be considerably shortened if CTC+ cells were enumerated using flow cytometry, presumably due to increased sensitivity of cytometry as compared to epifluorescence microscopy.

Another factor to consider in comparing results of studies using CTC to evaluate ETS activity in bacteria is how samples are incubated. The majority of investigators using this assay incubate small $(0.1$ to $2.0 \mathrm{ml})$ aliquots of liquid sample with CTC. Karner \& Fuhrman (1997), however, settled $30 \mathrm{ml}$ seawater samples onto membrane filters, flooded the filter surface with a $4 \mathrm{mM}$ CTC solution, and incubated the filters for periods of time. When we tested whether this mode of incubation could affect the percentage of CTC+ cells, we found that the percentages of CTC+ cells were not different for the liquid samples and the $3 \mathrm{ml}$ filtered samples, but were much less for the $30 \mathrm{ml}$ filtered samples (Table 1). This test suggests that the Karner \& Fuhrman (1997) membrane incubation method can yield good results with small sample volumes, but could result in underestimation of $\%$ CTC+ cells when tens of $\mathrm{ml}$ are settled onto a filter.

The application of flow cytometry for the detection of CTC+ cells has resulted in a significant improvement of the method. Kaprelyants \& Kell $(1993 a, b)$ first used flow cytometry to enumerate active cells of Micrococcus luteus in starvation-survival experiments. Del Giorgio et al. (1997) later extended the use of flow cytometry for the detection of natural bacterioplankton cells capable of reducing CTC. The application of flow cytometry offers 2 important advantages over conventional epifluorescence microscopy: (1) large numbers of CTC+ cells can be enumerated in very short times with minimal sample preparation; the precision of the cell counts is thus increased by an order of magnitude relative to microscopic counts (del Giorgio et al. 1997); and (2) incubation time of samples with CTC can be significantly reduced; often less than $1 \mathrm{~h}$ is enough to attain a maximum number of stained cells. In addition to cell counts, single-cell characteristics, such as rela- 
tive cell size and metabolic activity, can be derived from cytometric data (del Giorgio et al. 1996); the use of this additional information is discussed below with respect to the results of the manipulation experiment.

\section{CTC toxicity}

Toxicity of CTC or of its formazan precipitate to bacterial cells has been a major criticism of the technique (Davey \& Kell 1996, Ullrich et al. 1996, Karner \& Fuhrman 1997). Other authors have noted that at concentrations above 5 to $10 \mathrm{mM}$, or after long $(>20 \mathrm{~h})$ incubations at lower concentrations, both the number of CTC+ cells, and the total number of cells tend to decline (Rodriguez et al. 1992, del Giorgio \& Scarborough 1995, Choi et al. 1999). Epstein \& Rossel (1995), however, found that CTC-labeled bacteria continued to divide normally, and that these cells were not toxic to their flagellate grazers. If CTC or its products are toxic, this effect does not appear to be immediate. Del Giorgio et al. (1997) used flow cytometry to measure the intracellular accumulation of CT-formazan and noted that mean red fluorescence emission per cell continued to increase for several hours after the number of CTC+ cells had stabilized, indicating that cells continued to reduce CTC and accumulate formazan long after they were visibly stained under flow cytometry. These results further suggest that cells are not killed instantly, but rather continue to function for hours after exposure to CTC.

\section{Discrepancies between CTC, microautoradiography and ribosomal-RNA content as indices of 'active' bacteria}

Comparison of various cell-specific methods designed to distinguish active from inactive cells have resulted in large discrepancies in values for percent active cells in bacterioplankton assemblages. In particular, analyses based on microautoradiography and cell-specific rRNA content generally yield high (30 to $60 \%$ active) values (Riemann et al. 1984, Douglas et al. 1987, Kemp et al. 1993, Kramer \& Singleton 1993, Lee \& Kemp 1994, Karner \& Fuhrman 1997) compared to analysis of proportion of cells that reduce CTC (<10\% active) (Gasol et al. 1995, Lovejoy et al. 1996. Karner \& Fuhrman 1997). However, we argue that the first 2 approaches can score as positive non-growing cells in a state of 'starvation survival' (Kjelleberg et al. 1993. Morita 1997). Reduction of sufficient CTC for a cell to be scored as positive, on the other hand, appears to be a characteristic of actively growing cells.
The idea that most bacteria in seawater are dormant, i.e. in a state of starvation survival, is a long-standing one (Stevenson 1978, Morita 1982, 1997). There is a substantial literature on this topic (reviewed in Morita 1997). Bacteria in 'starvation survival' mode are not completely inactive; such cells are still able to take up substrate, and engage in low but measurable rates of biosynthesis (Kjelleberg et al. 1993). A repeated observation has been that when starved, marine bacteria change their substrate uptake mechanisms from low affinity to high affinity systems. Marden et al. (1987) demonstrated that an unidentified Gram-negative marine bacterium displayed 2 separate uptake systems with different affinities for leucine. When nutrient replete, cells took up leucine with a $\mathrm{K}_{\mathrm{m}}$ of $20 \mu \mathrm{M}$, but when starved, the $K_{m}$ for leucine decreased to $0.76 \mu \mathrm{M}$. Marden et al. (1987) stated that 'the capacity to scavenge and transport nutrients seems to be of utmost importance for substrate-starved cells'. Faquin \& Oliver (1984) found that a psychrophilic marine bacterium, Vibrio sp., was 'able to maintain a high-affinity, active transport system for arginine during extended periods of starvation'. Davis \& Robb (1985) showed that marine Vibrio sp. and Pseudomonas sp. were able to take up mannitol even after starvation for 5 to $6 \mathrm{wk}$, and that the Vibrio sp. switched from a low-affinity to a high-affinity uptake system for mannitol after $5 \mathrm{wk}$ of starvation. Albertson et al. (1990) demonstrated a similar switch in uptake systems for D-glucose in starved cells of another marine Vibrio sp. The results of these studies imply that bacteria which score positive in autoradiography assays, i.e. are able to take up radioactively labeled substrates added at nanomolar concentrations, are not necessarily very metabolically active or growing. It is important to note that label associated with cells in autoradiography assays could be present as unincorporated substrate as well as substrate incorporated into macromolecules.

Cell-specific content of rRNA has more recently been suggested as an index of active, as opposed to dead or dormant, cells (Kemp et al. 1993, Kramer \& Singleton 1993, Lee \& Kemp 1994, Karner \& Fuhrman 1997. Williams et al. 1998). However, as Jeffrey et al. (1996), Karner \& Fuhrman (1997) and Williams et al. (1998) concluded, the RNA content of bacteria is not consistently related to metabolic activity. Several studies have shown that during starvation, the amount of RNA in marine bacteria declines more slowly compared to other cell constituents, such as DNA (Hood et al. 1986, Moyer \& Morita 1989). Flardh et al. (1992) found that after $3 \mathrm{~d}$ of carbon starvation in a marine Vibrio sp., the relative amount of ribosomes was still $52 \%$ of the amount in actively growing cells. Jeffrey et al. (1996) reported that for mixed species assemblages of marine bacterioplankton; the cell-specific RNA: 
DNA ratios of suspended bacteria were not well correlated with rates of incorporation of radiolabeled thymidine and leucine.

It is apparent that for both microautoradiography and cell-specific rRNA content assays, bacterial cells that are non-growing, in a dormant or starvation survival state, can nevertheless be scored as active. Bacteria in a starvation survival state must maintain certain cell functions, such as maintenance of cell membrane integrity and active transport systems, and can carry out a low level of protein synthesis. These functions are essential to maintain cell viability and to resume growth when environmental conditions become favorable, and require a minimum expenditure of energy (Dawes 1985). Bacteria will utilize exogenous organic substrates to cover these basic maintenance requirements, even when growth is completely impeded. The existence of a large pool of bacteria that take up organic substrates for metabolic requirements not associated with growth implies that we may have to re-evaluate bacterial production assays based on the incorporation of radiolabeled precursors such as thymidine or leucine. For example, Simek (1986) concluded, using autoradiography, that only a small fraction of pelagic bacteria showed high uptake rates of organic molecules, whereas the majority took up labeled tracer substances at a rate close to zero. It has yet to be shown whether non-growth-associated leucine or thymidine uptake, which based on present methods specifically assays rate of incorporation of the label into macromolecules, could result in significant overestimates of net bacterial production.

\section{CTC reduction as a measure of highly metabolically active cells}

Whether starved bacteria meet their maintenance requirements with exogenous substrates or by endogenous metabolism, cells must sustain a minimum flow of energy and must therefore have a functional ETS. In fact, it would be misleading to assume that only CTC+ cells are respiring, because most starved bacteria that do not form specialized resistance forms must have some level of electron transport activity and respiration (Dawes 1985, Morita 1997). The CTC assay scores as positive cells that have reduced sufficient CTC to be detectable by epifluorescence microscopy or by flow cytometry. Those cells with relatively high rates of respiration are scored as CTC+, while the maintenance metabolism of non-growing cells apparently cannot be detected with the CTC assay. Thus, the CTC assay is not appropriate to differentiate cells that are alive or dead. From this point of view, autoradiography is a more sensitive assay because it can detect uptake of trace amounts of substrates by cells that are alive but not growing

Karner \& Fuhrman (1997) reported a large discrepancy between counts of active cells obtained using CTC and autoradiography and RNA contents, and they, as well as Ullrich et al. (1996), have suggested that the CTC assay grossly underestimates the actual number of metabolically active bacteria. We propose, however, that cells that are scored as CTC+ are responsible for the bulk of bacterial metabolism, including respiration and biomass production, and for most of the organic and inorganic nutrient uptake and release. We propose that such cells have greater metabolic activity compared to most cells that are scored as active by either autoradiography or by rRNA content. Although the distinction between highly active and less active cells is purely operational (based only on being $\mathrm{CTC}^{+}$or $\mathrm{CTC}_{-}$) we will argue in the following sections, based on current findings, that this distinction is ecologically relevant.

\section{Interpretation of CTC results}

Pyle et al. (1995) and others have reported high correlations between the number of CTC+ cells and conventional plate counts in cultures of several different types of bacteria. This suggests that for cultured bacteria the reduction of CTC represents a good analog for cell 'viability'. For natural planktonic bacteria, the interpretation of results obtained by CTC is less straightforward, because some of these bacteria may not be amenable to culture on agar plates. Choi et al. (1996) compared the number of CTC+ cells with those containing visible nucleoids (sensu Zweifel \& Hagström 1995), and found good correspondence between the 2 counts in actively growing cells, but higher percentages of cells with visible nucleoids compared to CTC+ cells for bacteria in stationary phase. Del Giorgio et al. (1997) showed that CTC+ cells have intact cell membranes. Bacterioplankton cells were doublestained with CTC and a membrane-impermeant stain, TOPRO- 1 , which is used as an indicator of cell damage or death (del Giorgio et al. in press). Cells that reduced CTC did not take up TOPRO-1, suggesting that CTC+ cells have intact membranes, at least during incubations lasting for less than $5 \mathrm{~h}$. As shown here, taxonomically diverse strains of aerobic, heterotrophic marine bacteria reduce CTC to its fluorescent product. Moreover, the proportion of CTC+ cells in laboratory cultures varies in meaningful ways: the proportion of $\mathrm{CTC}+$ cells is greatest for bacteria in log-phase growth, with values close to $100 \%$ being common, and lowest for bacteria in late stationary phase; plate counts of 'viable' bacteria usually agree very well with counts of 
active or CTC+ cells. All of this evidence suggests that, at least in culture conditions, CTC is an appropriate marker to differentiate highly active cells from relatively inactive and dormant or dead cells.

In all the instances where CTC has been used in natural water samples, the proportion of active cells is low, typically between $<1$ and $35 \%$ (Schaule et al. 1993, del Giorgio \& Scarborough 1995, Choi et al. 1996, del Giorgio et al. 1996, 1997, Lovejoy et al. 1996). An obvious concern is whether these low values of active cells are due to the failure of CTC to detect all cells that are metabolically active in the plankton. One major difference between natural bacterioplankton cells and cultured bacteria is the much larger size of the latter. It is conceivable that extremely small bacteria, characteristic of many natural aquatic systems, cannot be detected using CTC even if they are metabolically active. In a study of coastal marine bacterioplankton, Gasol et al. (1995) directly measured CTC+ cells using double staining with DAPI and image analysis and concluded that CTC+ cells were on average larger than CTC-cells, but these authors found CTC+ cells in all size categories, including the smallest cells ranging from 0.2 to $0.3 \mu \mathrm{m}$. These results suggest that the level of cell activity, rather than size, is what determines the detectability of respiring cells.

Evidence that use of CTC detects highly active cells is provided by the recent results of Choi et al. (1999). In this study, DNA synthesis inhibitors were added to seawater samples to retard bacterial cell division, and then organic substrates were added to determine the effect of substrate addition on proportion of visibly ETS-active cells using CTC. In these experiments, while the initial \% CTC+ values were less than $4 \%$, after $24 \mathrm{~h}$ of incubation with inhibitors and added substrates, up to $87 \%$ of cells became visibly CTC+ as assessed by microscopic examination, before increase in cell abundance was detected. The conclusion was that in freshly sampled seawater, the abundances of highly active bacteria were low, and that ETS activity could be enhanced in the majority of bacterial cells in these seawater samples via substrate addition. We have also observed that particle-associated bacteria in various marine environments exhibit a higher percentage of CTC+ cells compared to bacteria freely suspended in the water column (Fig. 1). Comparative studies (del Giorgio \& Scarborough 1995, del Giorgio et al. 1997) have further shown that both the number and proportion of CTC + cells vary systematically along gradients of productivity in natural aquatic systems. Highly productive systems tend to have more ETSactive cells, in absolute and relative terms, than unproductive systems. Not coincidentally, there is a weak but significant positive relationship between the proportion of CTC+ cells and rates of bacterial incorpora- tion of radiolabeled leucine and thymidine, that we have reported here, and elsewhere for lakes and estuaries (Lovejoy et al. 1996, del Giorgio et al. 1997), and that we discuss below.

\section{Relationship between highly active cells and bacterial community production and respiration}

Perhaps the most relevant information regarding the significance of the CTC method is the relationship between the number and proportion of CTC+ cells and rates of bacterial metabolism, particularly to the incorporation of leucine and/or thymidine. The incorporation rates of these substrates are generally used to estimate bacterial biomass production, although we mentioned above the possibility that some fraction of the uptake is by non-growing cells in starvation survival mode needs investigation. Total bacterial abundance is remarkably constant among systems, and rates of bacterial leucine and thymidine incorporation are orders of magnitude more variable than cell counts among aquatic systems (Ducklow \& Carlson 1992). Over wide ranges of system productivity, there is a positive relationship between bacterial abundance and substrate uptake (Cole et al. 1988), but over smaller ranges, this relationship often disappears (Ducklow \& Carlson 1992). A good example of this lack of relationship are the data from the manipulation experiments that we reported above. Total bacterial abundance varied by 4 -fold, whereas rates of leucine incorporation varied by 2 orders of magnitude among treatments, and none of the variance in rates of leucine incorporation can be explained by change in total bacterial abundance (Fig. 3A). Bacterial attributes other than total cell abundance must surely influence bacterial community activity. Previous comparative studies (Lovejoy et al. 1996, del Giorgio et al. 1997) have shown that over narrower ranges of lakes and estuaries, rates of bacterial production (assessed by radiolabeled leucine or thymidine incorporation) are much better correlated to the number of CTC+ cells than by the total number of cells, as would be expected if CTC+ cells are responsible for the bulk of bacterial activity. Likewise, Smith (1998) has shown that the rates of microbial $(<3 \mu \mathrm{m})$ respiration in Chesapeake Bay are strongly correlated to the abundance of CTC+ cells, and much less so to the total abundance of bacteria and water temperature. These results suggest that $\mathrm{CTC}+$ bacteria are responsible for the bulk of bacterial community metabolism, including respiration and the uptake of substrates.

In these studies, however, there was still much of the variance in bacterial metabolism that was not explained by the abundance of $\mathrm{CTC}+$ cells alone. This 
was also evident in the data from our manipulation experiment. The relationship between rates of leucine incorporation and cell counts improved slightly when the abundance of CTC+ cells was used as an independent variable (Fig. 3B), but this relationship was still weak. The large amount of unexplained variance in bacterial production led us to hypothesize that size and specific activity of CTC+ cells, combined with abundance of CTC+, should explain more of the variance in rates of bacterial production than the abundance of CTC+ cells alone (del Giorgio et al. 1997).

\section{Relevance of single-cell characteristics of highly active cells}

The grazing manipulation experiments that we report here were an opportunity to test the hypothesis that the best predictor of rates of bacterial production should be the combination of the abundance, size and individual activity of CTC+, because we had cytometric data on single-cell characteristics. From the point of view of assessing the impact of grazing by heterotrophic protozoans on bacterioplankton structure, our laboratory manipulations were not effective. An assemblage of very large and active bacteria, resistant to protozoan grazing, developed in the flagellate cultures, and were added to our natural assemblage of lake bacteria together with the flagellates. The high proportion of active cells and high rates of leucine uptake in the flagellate treatment were mostly due to these added bacteria. In the context of this paper, the main interest in these results is the large range in all measured parameters that resulted from the experimental manipulations, which covers much of the range found in natural freshwaters.

Bacterial biomass production has 2 components: one is the biomass of cells that are active and participate in growth and production, and the other is the specific metabolic rates of these cells. The biomass component can be approximated if we assume that CTC+ cells are the ones responsible for the bulk of leucine uptake, and can be calculated by multiplying the number of CTC+ cells by their relative size, as expressed by side light scatter (Davey \& Kell 1996). Overall rates of respiration of a bacterial assemblage can be approximated by the rate of formazan production (Burton \& Lanza 1986, Cook \& Garland 1997. Smith \& McFeters 1997), so we have assumed that the specific activity component may be derived from the amount of formazan produced per cell, which is approximated by the mean red fluorescence emission (FL3) per cell. Thus, the product of the abundance of active cells (CTC), their mean side light scatter ( $\mathrm{SSC}$ ), and their mean red fluorescence (CTC $\times$ SSC $\times$ FL3), should approximate the rates of leucine uptake, if indeed CTC+ cells are responsible for the bulk of bacterial production in the assemblage. There was a strong positive relationship between rates of leucine uptake and the expression CTC $\times$ SSC $\times$ FL3 (Fig. 3D). This expression was the best predictor of rates of leucine incorporation in our data set. These results support the hypothesis that CTC+ cells are responsible for the bulk of bacterial production in aquatic systems, even if these cells are not the only metabolically active ones in the assemblage. They also suggest that even if a much larger number of cells are capable of leucine (or thymidine) uptake, as is evident from most autoradiographic studies, the bulk of leucine incorporation is due to CTC+ bacteria.

It is thus clear that rates of substrate uptake are a function not only of the number of highly active bacteria, but also of their size and specific metabolic rates. Others have also found large shifts in cell-specific ETS activity, measured as the amount of formazan production, in response to environmental changes (Cook \& Garland 1997, Posch et al. 1997). The expression CTC $\times \mathrm{SSC} \times \mathrm{FL} 3$ showed a strong positive relationship with the proportion of active cells (Fig. 3D). Higher proportions of active cells correspond to more and larger active cells and higher specific metabolic rates of these cells. This relationship suggests that the proportion of cells that are capable of reducing CTC is related to ecologically important attributes of bacterioplankton assemblages, such as cell size, cell specific activity, and most importantly, bacterial production, and partly explains the positive relationship between bacterial production and proportion of active cells that has been observed in natural aquatic systems.

\section{Relationship of percent of CTC+ cells to controls of bacterial activity in situ}

An important corollary of the above discussion is that it is not just the number, but the proportion of CTC+ cells that is relevant to the functioning of microbial assemblages. The proportion of CTC+ or active cells does not vary at random; it tends to be low in oligotrophic systems and increases with system productivity. As opposed to total bacterial abundance, the number of CTC+ cells is highly variable among systems, and shows the same range of variation as bacterial production (del Giorgio \& Scarborough 1995). If the size and specific activity of active cells are also included, and we can now do this with the aid of flow cytometry, a much larger portion of the variation in bacterial production might be explained. Therefore, a relevant question in contemporary microbial ecology might be: what controls the proportion of active $(\mathrm{CTC}+)$ cells in 
aquatic systems, rather than what controls the total bacterial abundance.

An obvious potential control of ETS activity in heterotrophic bacteria is the availability of organic substrate (bottom-up control). The higher \% CTC+values found for particle-associated bacteria compared to freely suspended bacteria (Fig. 1) offers indirect evidence for substrate control of bacterial activity in situ. Bacteria on particles have a higher concentration of available substrate compared to suspended bacteria, and are more active as a result (Azam \& Ammerman 1984, Smith et al. 1992). At least 3 studies have also shown direct response of bacterial cells to substrate addition using CTC reduction as a cell-specific index of metabolic activity. Smith \& McFeters (1996) reported enhancement of the amount of CTC reduced by the ETS of whole Escherichia coli cells with addition of glucose, glycerol, succinate, formate, and lactate (Kalmbach et al. 1997). Choi et al. (1999) found an increase in the percentage of CTC+ cells in natural bacterioplankton assemblages when seawater samples were incubated for periods of $24 \mathrm{~h}$ or longer with added glucose, mixed amino acids, or yeast extract. The greatest enhancement of ETS activity found in the latter study was due to addition of amino acids and of yeast extract, which increased \% CTC+ values from time 0 values of 1.9 to 2.4 to 50 to $87 \%$ after incubation with the substrates for $24 \mathrm{~h}$. This enhancement occurred before significant cell growth was observed in the samples, and thus represented increased ETS activity in cells originally present in the bacterioplankton assemblages (Choi et al. 1999).

There is evidence that food web interactions may also play a key role in determining the proportion of active cells in aquatic systems, because highly active cells and dividing bacteria appear to be preferentially consumed (González et al. 1990, Sherr et al. 1992, del Giorgio et al. 1996). In previous experiments in marine waters (del Giorgio et al. 1996) we have shown that there is a tight inverse relationship between flagellate grazing rates and the proportion of CTC+ bacteria. Epstein \& Rossel (1995) also reported that CTC-labeled bacteria were preferentially removed by protozoans.

The grazing manipulation experiments we report here can also be used to exemplify the type of topdown control that might occur in natural systems. In these experiments, the proportion of CTC+ cells did not decline in the flagellate treatment compared to the control, as we had anticipated based on our previous experience. This was due to the development of highly active filamentous bacteria that were resistant to grazing in the flagellate treatment. Although we had not encountered this in any previous experiments with natural microbial assemblages, the development of grazing-resistant forms as a response to grazing in nat- ural assemblages has been well documented (Jürgens \& Güde 1994, Pernthaler et al. 1996), and has been related to the occurrence of certain taxonomic groups of bacteria (Pernthaler et al. 1997). It is clear then that the effect of protozoan grazing on the proportion of highly active cells depends not only on the intensity of flagellate grazing, but also on the composition of the bacterial assemblage. There were 2 contrasting effects in the Daphnia treatment: On the one hand, Daphnia stimulated single-cell activity and resulted in larger active cells, probably by releasing labile organic substrates and nutrients into the water. On the other, the net effect of Daphnia grazing was a decline in total bacterial abundance, but an increase in the proportion of active cells, suggesting that grazing by Daphnia was essentially size- and unselective. These patterns lead us to hypothesize that the proportion of active cells, as measured by the CTC method, might be a combined index of the predominant type of grazing that characterizes natural aquatic systems, as well of the availability of organic substrates.

\section{CONCLUSIONS}

We surmise that the CTC method, even with the uncertainties and limitations that we have discussed above, provides information which is relevant to current problems and questions in aquatic microbial ecology. The number and proportion of CTC+ cells, together with single-cell characteristics of these active cells, are related to mean cell size of the assemblage, to substrate availability and to rates of substrate uptake, and are probably also an index of amount and type of grazing in different systems. Our results, along with those of others, strongly suggest that determining the proportion of identifiably ETS-active cells using the CTC reduction assay does not lead to an underestimation of the abundance of highly metabolically active cells. The observed discrepancies between the proportion of CTC+ cells and the proportions of cells identified as active or living using other methods (e.g. Karner \& Fuhrman 1997) are instead, we argue, a difference in the degree of metabolic activity. Cells capable of reducing sufficient CTC to be identified as CTC+ should be viewed as the most highly active cells, while some portion of CTC-cells may be viable but have a much lower level of metabolic activity. Perhaps the greatest difficulty in the interpretation of CTC results is that it is presently difficult to determine quantitative differences in metabolism between 'highly active' CTC+ cells, and 'less active' CTC-cells, in mixed species bacterial assemblages.

We thus propose that the results of CTC reduction assays can be interpreted as identifying the most 
highly active cells in bacterioplankton populations or assemblages. As discussed above, cells that are not identifiably CTC+ in such assays are not necessarily devoid of metabolic activity. Choi et al. (1996) and Choi et al. (1999) have shown that a portion, and sometimes a large fraction, of supposedly 'inactive' bacterial cells can be induced to high metabolic activity by substrate addition. In contrast, alternative methods such as microautoradiography or methods which identify intact versus damaged bacterial cells likely include in the 'active' fraction non-growing cells that are a state of starvation survival. Methods such as determining cell-specific ETS activity via CTC reduction, which lend themselves to large scale comparative and experimental studies, are currently needed if we are to understand the internal dynamics of bacterioplankton across systems. More work will be required to determine if there is, as we suspect, a direct relationship between those cells that are actively growing and dividing, and cells that reduce sufficient CTC to be detected as CTC+.

Acknowledgements. We thank J. Cole, M. Pace and D. Bird for assistance in the manipulation experiments. P.d.G. was supported by a NSERC (Canadian Government) postdoctoral fellowship, and B.F.S. and E.B.S. by NSF Grant OCE-9633712.

\section{LITERATURE CITED}

Albertson NH, Nystrom T, Kjelleberg S (1990) Starvationinduced modulations in binding protein-dependent glucose transport by the marine Vibrio sp. S14. FEMS Microbiol Lett 70:205-210

Azam F, Ammerman JW (1984) Cycling of organic matter by bacterioplankton in pelagic marine ecosystems: microenvironmental considerations. In: Fasham MJR (ed) Flows of energy and materials in marine ecosystems. Plenum Publishing, New York, p 345-360

Baker KH, Mills AL (1982) Determination of the number of respiring Thiobacillus ferrooxidans cells in water samples by using combined fluorescent antibody-2-(p-iodophenyl)-3-(p-nitrophenyl)-5-phenyltetrazolium chloride staining. Appl Environ Microbiol 43:338-344

Bovill RA, Shallcross JA, Mackey BM (1994) Comparison of the fluorescent redox dye 5-cyano-2,3-ditolyltetrazolium chloride with $\mathrm{p}$-iodonitrotetrazolium violet to detect metabolic activity in heat-stressed listeria monocytogenes cells. J Appl Bacteriol 77:353-358

Burton GA, Lanza GR (1986) Variables affecting two electron transport system assays. Appl Environ Microbiol 51 931-937

Button DK, Schut F, Quang P, Martin R, Robertson BR (1993) Viability and isolation of marine bacteria by dilution culture: theory, procedures, and initial results. Appl Environ Microbiol 59:881-891

Choi JW, Sherr EB, Sherr BS (1996) Relation between presence-absence of a visible nucleoid and metabolic activity in bacterioplankton cells. Limnol Oceanogr 41:1161-1168

Choi JW, Sherr BF, Sherr EB (1999) Dead or alive? A large fraction of ETS-inactive marine bacterioplankton cells, as assessed by the reduction of CTC, can become ETS-active with incubation and a substrate addition. Aquat Microb Ecol 18:105-115

Coallier J, Provost M, Rompro A, Duchesne D (1994) The optimization and application of two viable count methods for bacteria in distributed drinking water. Can J Microbiol 40: $830-836$

Cole JJ, Findlay S, Pace M (1988) Bacterial production in fresh and saltwater: a cross-system overview. Mar Ecol Prog Ser 43:1-10

Cook KL, Garland JL (1997) The relationship between electron transport activity as measured by CTC reduction and $\mathrm{CO}_{2}$ production in mixed microbial communities. Microb Ecol 34:237-247

Davey HM, Kell DB (1996) Flow cytometry and cell sorting of heterogeneous microbial populations: the importance of single-cell analyses. Microbiol Rev 60:641-696

Davis CL, Robb FT (1985) Maintenance of different mannitol uptake systems during starvation in oxidative and fermentative marine bacteria. Appl Environ Microbiol 50: $743-748$

Dawes EA (1985) Starvation, survival and energy reserves. In: Fletcher M, Floodgate GM (eds) Bacteria in their natural environment. Academic Press, New York, p 43-79

del Giorgio PA, Scarborough G (1995) Increase in the proportion of metabolically active bacteria along gradients of enrichment in freshwater and marine plankton: implications for estimates of bacterial growth and production. J Plankton Res 17:1905-1924

del Giorgio PA, Gasol JM, Vaqué D, Mura P, Agusti S, Duarte CM (1996) Bacterioplankton community structure: protists control net production and the proportion of active bacteria in a coastal marine community. Limnol Oceanogr 41: $1169-1179$

del Giorgio PA, Prairie YT, Bird DF (1997) Coupling between rates of bacterial production and the number of metabolically active cells in lake bacterioplankton, measured using CTC reduction and flow cytometry. Microb Ecol 34: $144-154$

Douglas DJ, Novitsky JA, Fournier RO (1987) Microautoradiography-based enumeration of bacteria with estimates of thymidine-specific growth and production rates. Mar Ecol Prog Ser 36:91-99

Ducklow HW, Carlson CA (1992) Oceanic bacterial production. In: Marshall KC (ed) Advances in microbial ecology, Vol 12. Plenum Press, New York, p 113-181

Dufour P, Colon M (1992) The tetrazolium reduction method for assessing the viability of individual bacterial cells in aquatic environments: improvements, performance and applications. Hydrobiologia 232:211-218

Epstein SS (1997) Microbial food webs in marine sediments. I. Trophic interactions and grazing rates in two tidal flat communities. Microb Ecol 34:188-198

Epstein SS, Rossel J (1995) Methodology of in situ grazing experiments: evaluation of a new vital dye for preparation of fluorescently labeled bacteria. Mar Ecol Prog Ser 128: $143-150$

Faquin WC, Oliver JD (1984) Arginine uptake by a psychrophilic marine Vibrio sp. during starvation-induced morphogenesis. J Gen Microbiol 130:1331-1335

Flardh K, Cohen PS, Kjelleberg S (1992) Ribosomes exist in large numbers over the apparent demand for protein synthesis during carbon starvation in marine Vibrio sp. strain CCUG 15956. J Bacteriol 174:6780-6788

Gasol JM, del Giorgio PA (1999) Flow cytometric determination of cell abundance and structure of planktonic bacterial assemblages. Sci Mar (in press) 
Gasol JM, del Giorgio PA, Massana R, Duarte CM (1995) Active versus inactive bacteria: size dependence in a coastal marine plankton community. Mar Ecol Prog Ser 128:91-97

González JM, Sherr EB, Sherr BF (1990) Size-selective grazing on bacteria by natural assemblages of estuarine flagellates and ciliates. Appl Environ Microbiol 56:583-589

Grossman S (1994) Bacterial activity in sea ice and open water of the Weddell Sea, Antarctica: a microautoradiographic study. Microb Ecol 28:1-18

Heijnen CE, Page S, van Elsas JD (1995) Metabolic activity of Flavobacterium strain P25 during starvation and after introduction into bulk soil and the rhizosphere of wheat. FEMS Microbiol Ecol 18:129-138

Heissenberger A, Leppard GG, Herndl GJ (1996) Relationship between the intracellular integrity and the morphology of the capsular envelope in attached and free-living marine bacteria. Appl Environ Microbiol 62:4521-4528

Hood MA, Guckert JB, White DC, Feck F (1986) Effect of nutrient deprivation on lipid, carbohydrate, DNA, RNA, and protein levels in Vibrio cholerae. Appl Environ Microbiol 52:788-793

Jeffrey WH, Von Haven R, Hoch MP, Coffin RB (1996) Bacterioplankton RNA, DNA, protein content and relationships to rates of thymidine and leucine incorporation. Aquat Microb Ecol 10:87-95

Jepras RI, Carter J, Pearson SC, Paul FE, Wilkinson MJ (1995) Development of a robust flow cytometric assay for determining numbers of viable bacteria. Appl Environ Microbiol 61:2696-2701

Jürgens K, Güde H (1994) The potential importance of grazing-resistant bacteria in planktonic systems. Mar Ecol Prog Ser 112:169-188

Kalmbach S, Manz W, Szewzyk U (1997) Dynamics of biofilm formation in drinking water: phylogenetic affiliation and metabolic potential of single cells assessed by formazan reduction and in situ hybridization. FEMS Microbiol Ecol 22:265-279

Karner M, Furhman JA (1997) Determination of active marine bacterioplankton: a comparison of universal 16s rRNA probes, autoradiography, and nucleoid staining. Appl Environ Microbiol 63:1208-1213

Kaprelyants AS, Kell DB (1993a) Dormancy in stationaryphase cultures of Micrococcus luteus: flow cytometric analysis of starvation and resuscitation. Appl Environ Microbiol 59:3187-3196

Kaprelyants AS, Kell DB (1993b) The use of 5-cyano-2,3ditolyletrazolium chloride and flow cytrometry for the visualization of respiratory activity in individual cells of Micrococcus luteus. J Microbiol Methods 17:115-122

Kemp PF, Lee S, LaRoche J (1993) Estimating growth rate of slowly growing marine bacteria from RNA content. Appl Environ Microbiol 59:2594-2601

Kjelleberg S, Flardh KBG, Nystrom T, Moriarty DJW (1993) Growth limitation and starvation of bacteria. In: Ford TE (ed) Aquatic microbiology, an ecological approach. Blackwell Scientific Publications, Boston, p 289-320

Kramer JG, Singleton FL (1993) Measurement of rRNA variations in natural communities of microorganisms on the southeastern U.S. continental shelf. Appl Environ Microbiol 59:2430-2436

Langer EM (1985) The demonstration of succinate dehydrogenase activity in ascites tumor cells with fluorescent tetrazolium salts. Acta Histochem 76:23-28

Lee S, Fuhrman JA (1991) Spatial and temporal variation of natural bacterioplankton assemblages studied by total genomic DNA cross-hybridization. Limnol Oceanogr 36:
$1277-1287$

Lee S, Kemp PF (1994) Single cell RNA content of natural marine planktonic bacteria measured by hybridization with multiple $16 \mathrm{~S}$ rRNA targeted fluorescent probes. Limnol Oceanogi 39:869-879

Lopez-Amoros R, Comas J, Vives-Rego J (1995) Flow cytometric assessment of Escherichia coli and Salmonella typhimurium starvation-survival in seawater using rhodamine 123, propidium iodide, and oxonol. Appl Environ Microbiol 61:2521-2526

Lovejoy C, Legendre L, Klein B, Tremblay JE, Ingram RG, Therriault JC (1996) Bacterial activity during early winter mixing (Gulf of St. Lawrence, Canada). Aquat Microb Ecol 10:1-13

Marden P, Nystrom T, Kjelleberg S (1987) Uptake of leucine by a marine Gram-negative heterotrophic bacterium during exposure to starvation conditions. FEMS Microbiol Ecol 45:233-241

Mason JD, Lopez-Amoros R, Allman R, Stark MJ, Lloyd D (1995) The ability of membrane potential dyes and calcafluor white to distinquish between viable and nonviable bacteria. J Appl Bacteriol 78:309-315

McFeters GA, Yu FP, Pyle BH, Stewart PS (1995) Physiological assessment of bacteria using fluorochromes. J Microbiol Methods 21:1-13

Meyer-Reil LA (1978) Autoradiography and epifluorescence microscopy combined for the determination of number and spectrum of actively metabolizing bacteria. Appl Environ Microbiol 36:506-512

Morita RY (1982) Starvation-survival of heterotrophs in the marine environment. Adv Microbiol Ecol 6:171-178

Morita RY (1997) Bacteria in oligotrophic environments. Chapman and Hall, New York

Moyer CL, Morita RY (1989) Effect of growth rate and starvation-survival on cellular DNA, RNA, and protein of a psychrotrophic marine bacterium. Appl Environ Microbiol 55: $2710-2716$

Newell SY (1984) Modification of the gelatin-matrix method for enumeration of respiring bacterial cells, for use with salt-marsh water samples. Appl Environ Microbiol 47: 873-875

Newell SY, Fallon RD, Tabor PS (1986) Direct microscopy of natural assemblages. In: Poindexter JS, Leadbetter ER (eds) Bacteria in nature. Plenum Publishing, New York, p $1-48$

Nybroe O (1995) Asssessment of metabolic activity of single bacterial cells - new developments in microcolony and dehydrogenase assays. FEMS Microbiol Ecol 17:77-84

Nystrom T, Albertson NH, Flardh K, Kjelleberg S (1990) Physiological and molecular adaptation to starvation and recovery from starvation by the marine Vibrio sp. S14. FEMS Microbiol Ecol 74:129-140

Pedrós-Alió C, Newell SY (1989) Microautoradiographic study of thymidine uptake in brackish waters around Sapelo Island, Georgia, USA. Mar Ecol Prog Ser 55:83-94

Pernthaler J, Sattler B, Simek K, Schwarzenbacher, Psenner R (1996) Top-down effects on the size-biomass distribution of a freshwater bacterioplankton community. Aquat Microb Ecol 10:255-263

Pernthaler J, Posch T, Simek K, Vrba J, Amann R, Psenner R (1997) Contrasting bacterial strategies to coexist with a flagellate predator in an experimental microbial assemblage. Appl Environ Microbiol 63:596-601

Posch I, Pernthaler J, Alfreider A, Psenner R (1997) Cell-specific respiratory activity of aquatic bacteria studied with the tetrazolium reduction method, cyto-clear slides, and image analysis. Appl Environ Microbiol 63:867-873 
Pyle BH, Broadaway SC, McFeters GA (1995) Factors affecting the determination of respiratory activity on the basis of cyaroditolyl tetrazolium chloride reduction with membrane filtration. Appl Environ Microbiol 61: $4304-4309$

Riemann B, Niesen P, Jeppesen M, Marcussen B, Fuhrman JA. (1984) Diel changes in bacterial biomass and growth rates in coastal environments, determined by means of thymidine incorporation into DNA, frequency of dividing cells (FDC), and microautoradiography. Mar Ecol Prog Ser $17: 227-235$

Rodriguez GG, Phipps D, Ishiguro K, Ridgway HF (1992) Use of a fluorescent redox probe for direct visualization of actively respiring bacteria. Appl Environ Microbiol 58: 1801-1808

Roszak DB, Colwell RR (1987) Survival strategies of bacteria in the natura! environment. Microbiol Rev 51:365-379

Schaule G, Flemming HC, Ridway HF (1993) Use of 5-cyano2,3-ditolyl tetrazolium chloride for identifying planktonic and sessile respiring bacteria in drinking water. Appl Environ Microbiol 59:3850-3857

Severin E, Seidler E (1992) Calibration of a flow cytometric assay of glucose-6-phosphate dehydrogenase activity. Cytometry 13:322-326

Sherr BF, Sherr EB, McDaniels J (1992) Effect of protistan grazing on the frequency of dividing cells in bacterioplankton. A.ppl Environ Microbiol 58:2381-2385

Simek K (1986) Bacterial activity in a reservoir determined by autoradiography and its relationship to phyto- and zooplankton. Int Rev Ges Hydrobiol 71:593-612

Smith DC, Azam F (1992) A simple, economical method for measuring bacterial protein synthesis rates in seawater using ${ }^{3} \mathrm{H}$-leucine. Mar Microb Food Webs 6:107-114

Smith DC, Simon M, Alldredge AL, Azam F (1992) Intense hydrolytic enzyme activity on marine aggregates and implications for rapid particle dissolution. Nature 359: $139-142$

Smith EM (1998) Coherence of microbial respiration rate and cell-specific bacterial activity in a coastal planktonic community. Aquat Microb Ecol 16:27-35

Smith JJ, McFeters GA (1996) Effects of substrates and phosphate on INT (2-(4-idophenyl-3-(4-nitrophenyl)-5-phenyl tetrazolium chloride) and CTC (5-cyano-2,3-ditoyl tetrazolium chloride) reduction in Escherichia coli. J Appl Bacteriol 80:209-215

Smith JJ, McFeters GA (1997) Mechanisms of INT (2-(4-

Editorial responsibility: David Karl,

Honolulu, Hawaii, USA idophenyl-3-(4-nitrophenyl)-5-phenyl tetrazolium chloride) and CTC (5-cyano-2,3-ditoyl tetrazolium chloride) reduction in Escherichia coli $\mathrm{K}-12$. J Microbiol Methods 29:161-175

Stellmach J (1984) Fluorescent redox dyes 1. Production of fluorescent formazan by unstimulated and phorbol esteror digitonin-stimulated Ehrlich ascites tumor cells. Histochemistry $80: 137-143$

Stevenson LH (1978) A case for bacterial dormancy in aquatic systems. Microb Ecol 4:127-133

Suzuki MT, Rappe MS, Haimberger ZW, Winfield H, Adair N, Strobel J, Giovannoni SJ (1997) Bacterial diversity among small-subunit rRNA gene clones and cellular isolates from the same seawater sample. Appl Environ Microbiol 63: 983-989

Tabor PS, Neihof RA (1982) Improved microautoradiographic method to determine individual microorganisms active in substrate uptake in natural waters. Appl Environ Microbiol 44:945-953

Thom SM, Horobin RW, Seidler E, Barer MR (1993) Factors affecting the selection and use of tetrazolium salts as cytochemical indicators of microbial viability and activity. J Appl Bacteriol 74:433-443

Ullich S, Karrasch B, Hoppe HG, Jeskulke K, Mehrens M (1996) Toxic effects on bacterial metabolism of the redox dye 5-cyano-2,3-ditolyl tetrazolium chloride. Appl Environ Microbiol 62:4587-4593

Winding A, Binnerup SJ, Sorensen J (1994) Viability of indigenous soil bacteria assayed by respiratory activity and growth. Appl Environ Microbiol 60:2869-2875

Williams SC, Hong Y, Danavall DCA, Howard-Jones MH, Gibson D, Frischer ME, Verity PG (1998) Distinguishing between living and nonliving bacteria: evaluation of the vital stain propidium iodide and the combined use with molecular probes in aquatic samples. $J$ Microbiol Methods 32:236-255

Yu FP, McFeters GA (1994) Rapid in situ assessment of physiological activities in bacterial biofilms using fluorescent probes. J Microbiol Methods 20:1-10

Zimmerman R, Iturriaga R, Becker-Birck J (1978) Simultaneous determination of the total number of aquatic bacteria and the number thereof involved in respiration. Appl Environ Microbiol 36:926-935

Zweifel UL, Hagström $\AA$ (1995) Total counts of marine bacteria include a large fraction of non-nucleoid containing bacteria (ghosts). Appl Environ Microbiol 61:2180-2185

Submitted: March 24, 1998; Accepted: November 4, 1998

Proofs received from author(s): July 13, 1999 